\title{
Antioxidative nanofullerol prevents intervertebral disk degeneration
}

\author{
This article was published in the following Dove Press journal: \\ International Journal of Nanomedicine \\ 15 May 2014 \\ Number of times this article has been viewed
}

\author{
Xinlin Yang' \\ Li Jin' \\ Lu Yao ${ }^{2,3}$ \\ Francis H Shen' \\ Adam L Shimer' \\ Xudong $\mathrm{Li}^{\prime}$ \\ 'Orthopaedic Research Laboratories, \\ University of Virginia, Charlottesville, \\ VA, USA; ${ }^{2}$ School of Life Science, \\ Beijing Institute of Technology, Beijing, \\ People's Republic of China; ${ }^{3}$ Research \\ Institute of Beijing Tongrentang Co., \\ Ltd, Beijing, People's Republic of \\ China
}

Correspondence: Xudong (Joshua) Li Orthopaedic Research Laboratories, School of Medicine, Cobb Hall - B039, University of Virginia, Hospital Drive, PO Box 800374, Charlottesville, VA 22908, USA

Tel +I 4349824135

Fax + | 434924 |69|

Email xl2n@virginia.edu

\begin{abstract}
Compelling evidence suggests that reactive oxygen species (ROS) play a pivotal role in disk degeneration. Fullerol nanoparticles prepared in aqueous solution have been demonstrated to have outstanding ability to scavenge ROS. In this report, in vitro and in vivo models were used to study the efficacy of fullerol in preventing disk degeneration. For in vitro experiments, a pro-oxidant $\mathrm{H}_{2} \mathrm{O}_{2}$ or an inflammatory cytokine interleukin (IL)-1 $\beta$ was employed to induce degenerated phenotypes in human nucleus pulposus cells encapsulated in alginate beads, and fullerol was added in the culture medium. For the animal study, an annulus-puncture model with rabbit was created, and fullerol was injected into disks. It was shown that cytotoxicity and cellular ROS level induced by $\mathrm{H}_{2} \mathrm{O}_{2}$ were significantly diminished by fullerol. IL- $1 \beta$-induced nitric oxide generation in culture medium was suppressed by fullerol as well. Gene-profile and biochemical assays showed that fullerol effectively reversed the matrix degradation caused by either $\mathrm{H}_{2} \mathrm{O}_{2}$ or IL-1 $\beta$. The animal study delineated that intradiskal injection of fullerol prevented disk degeneration, increasing water and proteoglycan content and inhibiting ectopic bone formation. These results suggest that antioxidative fullerol may have a potential therapeutic application for disk degeneration.
\end{abstract}

Keywords: free radical, extracellular matrix, intervertebral disk, antioxidant, fullerol

\section{Introduction}

Lower-back pain is the leading cause of disability in people under the age of 45 years, and accounts for a US\$90 billion loss annually. ${ }^{1,2}$ The pathogenesis of this disease is still unclear. It is closely associated with the degeneration of intervertebral disks, which usually begins in the second decade of life and becomes increasingly severe with age. ${ }^{3,4}$ A disk is composed of three components: the central nucleus pulposus (NP), the surrounding annulus fibrosus (AF), and the upper and lower end plates. Disk degeneration represents remarkable changes in these components, including the loss/ alteration of cell viability and functionality, the destruction of extracellular matrix, and ectopic ossification. . $^{5-11}$

Oxidative stress is a cellular state with an increased level of reactive oxygen species (ROS) that is caused by an imbalance of generation and removal of these species. Singlet oxygen, superoxide anions, hydroxyl radicals, and nitric oxide (NO) are examples of ROS synthesized in cells. They are generated from normal metabolic processes in mitochondria, peroxisomes, and cytosol. Exposure to certain chemical and physical environments leads to production of ROS. ${ }^{12,13}$ On the other hand, removal of ROS within tissues and cells is carried out by both enzymatic and nonenzymatic antioxidative protective mechanisms. ${ }^{12,13}$ 
There is emerging evidence indicating that ROS is involved in progressive degenerative diseases of different skeletal tissues. ${ }^{14,15}$ In disk tissues, oxidative stress may initiate or participate in matrix destruction and cell apoptosis, which ultimately result in disk degeneration. ${ }^{16}$ It has been shown that the increase of exogenous NO may promote cell apoptosis and suppress proteoglycan synthesis in cultured disk cells. NO has been demonstrated to participate in the disk degeneration induced by mechanical stress or interleukin (IL)-1. ${ }^{17-21}$ Oxidative stress induced by the addition of hydrogen peroxide $\left(\mathrm{H}_{2} \mathrm{O}_{2}\right)$ caused apoptosis of rat NP cells and human AF cells. ${ }^{22,23}$ In addition, "brown degeneration" of the collagen framework is thought to be closely associated with age-related disk degeneration, and is a consequence of the nonenzymatic glycoxidation of matrix lysyl residues under cumulative oxidative stress. ${ }^{24-26}$

We hypothesize that antioxidants are potentially good therapeutic candidates to treat disk degeneration, because of their ability to scavenge ROS that lead to the injury of cellular functions in disk tissues. Fullerenes are extremely powerful antioxidants with unique nanostructures, and superior to conventional antioxidants due to their long-lasting activity and excellent cell membrane-penetrating ability. ${ }^{27}$ In this study, we found that fullerol (a polyhydroxylated derivative of fullerene) had a preventive effect on disk degeneration, highlighting its potential use as a therapeutic agent for the treatment of lower-back pain.

\section{Materials and methods}

\section{Characterization and measurement of aqueous fullerol nanoparticle scavenging activity}

Fullerol $\left(\mathrm{C}_{60}[\mathrm{OH}]_{22-24}\right.$; Materials and Electrochemical Research, Tucson, AZ, USA) was suspended in distilled water at room temperature. The resultant nanoparticle suspension was filtered with a $0.22 \mu \mathrm{m}$ membrane, and the resultant solution was then characterized by ultravioletvisible (UV-vis) spectrometry, dynamic light-scattering, and zeta-potential analyses, as previously described by us. ${ }^{28}$ The scavenging efficiencies of nanofullerol against superoxide anions, hydroxyl radicals, and NO were further determined by the pyrogallol autoxidation, ${ }^{29}$ Fenton-type reaction, ${ }^{30}$ and Griess reaction. ${ }^{31}$ Superoxide dismutase (SOD) or mannitol was used as a control for the scavenger of superoxide anions or hydroxyl radicals. The production of NO was detected by a commercial Griess reagent system kit (Promega, Fitchburg, WI, USA) using the protocol attached.

\section{Cell isolation and culture}

Human intervertebral disk samples were obtained from the surgical waste of individuals (age 13-16 years) who had undergone diskectomy for surgical management of scoliosis. NP tissues were cut into small pieces and digested with $0.01 \%$ collagenase (Crescent Chemical, Islandia, NY, USA) at $37^{\circ} \mathrm{C}$ for 3 hours. The isolated cells were cultured in Dulbecco's Modified Eagle's Medium/F-12 (Life Technologies, Carlsbad, CA, USA) containing $10 \%$ fetal bovine serum (FBS; Life Technologies), 100 units $/ \mathrm{mL}$ of penicillin, and $100 \mathrm{mg} / \mathrm{mL}$ of streptomycin. ${ }^{32}$ Cells with passages 4-6 were used for all experiments.

\section{Cytotoxic assay of nanofullerol}

Human NP cells were seeded in a 96-well plate $\left(1 \times 10^{4} /\right.$ well $)$ and incubated with culture medium overnight. Cells were then treated with various doses $(0,0.1,0.3,1,3,10 \mu \mathrm{M})$ of fullerol in medium (without phenol red) with $1 \%$ FBS for 4 hours $(200 \mu \mathrm{L} /$ well). The cytotoxic assay was performed with a commercial lactate dehydrogenase (LDH) kit (BioVision, Mountain View, CA, USA) according to the manufacturer's manual.

\section{Cell-alginate bead preparation}

The preparation of beads has been described in our previously published paper. ${ }^{32}$ Briefly, cell-alginate beads were formed on a $\operatorname{Costar}^{\circledR}$ ultralow-attachment 96-well plate (Corning, Tewksbury, MA, USA) by dropwise addition of cell suspension $\left(2 \times 10^{6} / \mathrm{mL}\right)$ in $1.2 \%$ alginate saline solution $(25 \mu \mathrm{L} /$ drop $)$ to $0.102 \mathrm{M} \mathrm{CaCl}_{2}(200 \mu \mathrm{L} /$ well $)$. Ten minutes later, beads were immersed in culture medium for 10 minutes.

\section{Hydrogen peroxide and nanofullerol treatment}

Cell beads were cultured for 36 hours in culture medium and then treated with $\mathrm{H}_{2} \mathrm{O}_{2}$, with or without nanofullerol in serum-free medium for 4 hours. Cell viability and ROS were assessed with a cell live/dead staining kit and a fluorescent $\mathrm{H}_{2}-2^{\prime}, 7^{\prime}$-dichlorofluorescein diacetate (DCFDA) dye (Life Technologies), respectively. For analyses of cell apoptosis, human NP cells were cultured with 10\% FBS medium for 60 hours. Apoptotic cells were determined by a terminal deoxynucleotidyl transferase-mediated deoxyuridine triphosphatase nick-end labeling staining kit (Roche, Basel, Switzerland) according to the manufacturer's manual. Microphotographs were taken under an Olympus BX51 microscope equipped with an Olympus DP70 digital camera (Olympus, Tokyo, Japan). The dead and apoptotic cells 
were quantified with ImageJ software (National Institutes of Health, Bethesda, MD, USA) by measuring the fluorescence density of five randomly selected areas.

\section{IL-I $\beta$ and nanofullerol treatment}

Cell beads were cultured in culture medium for 36 hours, and then treated with IL-1 $\beta$ with or without nanofullerol for up to 7 days. Nitrite in culture medium was measured with the Griess reagent after 3 days of culture. ${ }^{31}$

\section{GAG assay}

After 60 hours of treatment with $\mathrm{H}_{2} \mathrm{O}_{2}$, cell beads were dissolved in a depolymerizing buffer $(55 \mathrm{mM}$ sodium citrate, $30 \mathrm{mM} \mathrm{Na}$-ethylenediaminetetraacetic acid, and $0.15 \mathrm{M}$ sodium chloride [pH 6.8]). Cell-associated glycosaminoglycan (GAG) and cellular deoxyribonucleic acid (DNA) contents were measured according to our published protocols. ${ }^{33}$ Briefly, cells were incubated with $125 \mathrm{mg} / \mathrm{mL}$ of papain solution ( $\mathrm{pH}$ 6.5; Sigma-Aldrich, St Louis, MO, USA) at $60^{\circ} \mathrm{C}$ for 16 hours. The GAG content was determined by the dimethylmethylene blue colorimetric assay with chondroitin sulfate (Sigma-Aldrich) as a standard. DNA contents were measured with a fluorescent Hoechst 33258 dye (SigmaAldrich) using calf thymus DNA as a standard.

\section{Gene expression}

Ribonucleic acid (RNA) isolation and complementary DNA (cDNA) synthesis were performed with the RNeasy minikit (Qiagen Sciences, Germantown, MA, USA) and the iScript cDNA synthesis kit (Bio-Rad Laboratories, Hercules, CA, USA), respectively, following manufacturers' instructions.
Quantitative reverse transcription polymerase chain reaction (RT-PCR) was performed with iTaq SYBR Green Supermix (Bio-Rad Laboratories) using $18 \mathrm{~S}$ ribosomal RNA as an internal control. The target genes include extracellular matrix genes (aggrecan, type I and type II collagens [COL I and COL II]), matrix-degrading enzyme genes (matrix metalloproteinase [MMP]-3, MMP9, ADAMTS [a disintegrin and MMP with thrombospondin motifs]-5, and tissue inhibitor of metalloproteinase [TIMP]-1). Gene primers are listed in Table 1.

\section{Immunofluorescence staining}

Cell beads were fixed with $4 \%$ paraformaldehyde for 1 hour and embedded in Tissue-Tek ${ }^{\circledR}$ optimum cutting temperature compound (Sakura Finetek, Alphen aan den Rijn, the Netherlands) at $-70^{\circ} \mathrm{C}$. Sections $5 \mu \mathrm{m}$ thick were prepared with a CM3050 S cryostat (Leica Microsystems, Wetzlar, Germany). Aggrecan or COL II were stained with a mouse antiaggrecan (H-300, sc-25674) or anti-COL2A1 (sc-59958) antibody, and visualized with fluorescein isothiocyanateconjugated goat antimouse immunoglobulin G (sc-2010). All antibodies were purchased from Santa Cruz Biotechnology (Santa Cruz, CA, USA).

\section{Surgical procedure}

The use of animals was approved by the Institutional Animal Care and Use Committee at the University of Virginia. Ten mature female New Zealand White rabbits (age 8 months, average weight about $3.5 \mathrm{~kg}$ ) were randomly divided into two groups: 4-week and 12-week studies. After anesthesia, the anterior surfaces of three lumbar disks (L2/ L3-L4/L5) per rabbit were exposed by a posterior-lateral

Table I Primer sequences used for real-time polymerase chain reaction

\begin{tabular}{|c|c|c|}
\hline Molecule & Primer sequence & Size of product (bp) \\
\hline \multirow[t]{2}{*}{ Aggrecan (AGG) } & 5'-CGC TAC TCG CTG ACC TTT-3' (sense) & 106 \\
\hline & 5'-GCT CAT AGC CTG CTT CGT-3' (antisense) & \\
\hline \multirow[t]{2}{*}{ Collagen la I (COL I) } & 5'-GCC ATC AAA GTC TTC TGC-3' (sense) & 145 \\
\hline & 5'-ATC CAT CGG TCA TGC TCT-3' (antisense) & \\
\hline \multirow[t]{2}{*}{ Collagen Ila I (COL II) } & 5'-TCC CAG AAC ATC ACC TAC C-3' (sense) & 131 \\
\hline & 5'-AAC CTG CTA TTG CCC TCT-3' (antisense) & \\
\hline \multirow[t]{2}{*}{ Matrix metalloproteinase 3 (MMP3) } & 5'-TGA AGA GTC TTC CAA TCC TAC TGT TG-3' (sense) & 113 \\
\hline & 5'-CTA GAT ATT TCT GAA CAA GGT TCA TGC-3' (antisense) & \\
\hline \multirow[t]{2}{*}{ Matrix metalloproteinase 9 (MMP9) } & 5'-CCC GGA GTG AGT TGA ACC A-3' (sense) & 86 \\
\hline & 5'-CAG GAC GGG AGC CCT AGT C-3' (antisense) & \\
\hline \multirow{2}{*}{$\begin{array}{l}\text { A disintegrin and metalloproteinase with } \\
\text { thrombospondin motifs } 5 \text { (ADAMTS5) }\end{array}$} & 5'-GGA CCT ACC ACG AAA GCA GAT C-3' (sense) & 112 \\
\hline & 5'-GCC GGG ACA CAC GGA GTA-3' (antisense) & \\
\hline \multirow[t]{2}{*}{ Tissue inhibitor of metalloproteinase I (TIMPI) } & 5'-GGG CTTCAC CAA GAC CTA CA-3' (sense) & 71 \\
\hline & 5'-TGC AGG GGA TGG ATA AAC AG-3' (antisense) & \\
\hline \multirow[t]{2}{*}{$18 \mathrm{~S}$} & 5'-GTG ACC AGT TCA CTC TTG GT-3' (antisense) & 99 \\
\hline & 5'-GAA TCG AAC CCT GAT TCC CCG TC-3' (antisense) & \\
\hline
\end{tabular}


retroperitoneal approach. Disks were punctured with an $18 \mathrm{G}$ needle to induce disk degeneration. Simultaneously, $25 \mu \mathrm{L}$ of nanofullerol suspension $(40 \mu \mathrm{g} / \mathrm{mL})$ or phosphate-buffered saline was injected into the selected disks.

\section{Imaging, histology, and biochemistry}

Mid-sagittal $\mathrm{T}_{2}$-weighted magnetic resonance imaging (MRI) was performed immediately after isolation of disks at each time point. Disks at L2/L3, L3/L4 and L4/L5 levels were then carefully dissected. For histology, the harvested disks ( $n=3$ ) were fixed, decalcified, and paraffin-embedded. Sections of $6 \mu \mathrm{M}$ thickness from the middle of the disk were stained with Safranin O (Sigma-Aldrich). In addition, disk tissues without endplates $(n=2)$ were harvested for both GAG and DNA contents, which were then measured as described earlier.

\section{Statistical analysis}

Data are presented as means \pm standard deviation. Student's two-tailed $t$-test was used for data analysis, with a $P$-value of 0.05 or less considered significant.

\section{Results}

\section{Radical scavenging activities of aqueous fullerol nanoparticles}

It has been reported that the aqueous solution of fullerol molecules aggregate to form nanoparticles. ${ }^{34}$ In the present experiments, the absorption peak of fullerol suspension was $293 \mathrm{~nm}$ with UV-vis spectrum measurement (Figure 1A). Dynamic light-scattering analysis revealed a particle size between 25 and $45 \mathrm{~nm}$ (Figure 1B). The nanoparticles were negatively charged with an average potential between -40 and $-60 \mathrm{mV}$, as measured by a zeta-potential analyzer (Figure 1C). In addition, the nanofullerol suspension was stable for up to 1 month in the dark at room temperature, and suitable for use in biological assays over the same period of time.

Scavenging activity against superoxide anions was determined by a pyrogallol autoxidation method (Figure 1D). SOD is a biologically derived antioxidative enzyme that elicits strong scavenging activity against superoxide anions. The nanofullerol suspension eliminated the radical in a dosedependent manner. At $50 \mu \mathrm{M}$, the activity of nanofullerol was approximately that of SOD at $25 \mathrm{U} / \mathrm{mL}$. Similarly, nanofullerol at $25 \mu \mathrm{M}$ reduced hydroxyl radicals at a rate equivalent to that of mannitol between 1 and $10 \mathrm{mM}$, measured by the Fenton-type reaction (Figure 1E). Furthermore, measured with a commercial Griess reagent system (Promega), NO was demonstrated to be scavenged by nanofullerol in a dosedependent fashion (Figure 1F).

\section{Nanofullerol reduces the cytotoxicity and ROS of hydrogen peroxide-treated human NP cells}

We first tested the cytotoxicity of nanofullerol at various doses ranging from 0 to $10 \mu \mathrm{M}$ in human NP cells. After 4 hours' treatment in a monolayer culture, LDH assay demonstrated that nanofullerol from 0 to $10 \mu \mathrm{M}$ was not harmful toward human NP cells (Figure 2A). Based on our preliminary findings, $1 \mu \mathrm{M}$ nanofullerol was chosen for all in vitro experiments. We further confirmed that $1 \mu \mathrm{M}$ nanofullerol treatment caused no toxicity in human NP cell-bead culture for up to 7 days with $\mathrm{YOYO}^{\circledR}-1$ (a fluorescent dye which stains only dead cells, data not shown; Life Technologies) staining. It was also observed by a commercial live/dead staining kit that $1 \mu \mathrm{M}$ nanofullerol treatment significantly reversed the cell damage caused by $\mathrm{H}_{2} \mathrm{O}_{2}(500 \mu \mathrm{M}, 4$ hours) (Figure 2B and $\mathrm{E})$. As expected, the ROS level, detected with a fluorescent $\mathrm{H}_{2}$ DCFDA dye, markedly increased with the treatment of $\mathrm{H}_{2} \mathrm{O}_{2}$. However, this increase was diminished by coadministration of $1 \mu \mathrm{M}$ nanofullerol (Figure $2 \mathrm{~F}-\mathrm{H}$ ).

\section{Nanofullerol protects against $\mathrm{H}_{2} \mathrm{O}_{2}$ - or IL-I $\beta$-induced matrix destruction}

We further examined the effects of nanofullerol on extracellular matrix destruction caused by oxidative stress or inflammatory cytokines in human NP cells. It was found that treatment with $\mathrm{H}_{2} \mathrm{O}_{2}$ significantly reduced the GAG content (Figure 3A) and the cellular amount of aggrecan (Figure 3B, upper panel). However, cotreatment with nanofullerol reversed the adverse effects of $\mathrm{H}_{2} \mathrm{O}_{2}$. Similarly, cotreatment with nanofullerol increased COL II expression compared to treatment of $\mathrm{H}_{2} \mathrm{O}_{2}$ alone (Figure 3B, lower panel).

The gene expression of aggrecan, COL I, and COL II was examined by real-time RT-PCR. In the presence of $\mathrm{H}_{2} \mathrm{O}_{2}$, messenger RNA (mRNA) levels of the three genes decreased significantly. Cotreatment with nanofullerol had no effect on COL I or COL II (Figure 3C). The mRNA level of aggrecan decreased further after treatment with fullerol and $\mathrm{H}_{2} \mathrm{O}_{2}$ compared to $\mathrm{H}_{2} \mathrm{O}_{2}$ alone. While $\mathrm{H}_{2} \mathrm{O}_{2}$ caused a significant elevation in mRNA expression of matrix-degradation enzymes $M M P 3, M M P 9$, and ADAMTS5, nanofullerol abolished the effect (Figure 3C). Neither $\mathrm{H}_{2} \mathrm{O}_{2}$ alone nor the combination of $\mathrm{H}_{2} \mathrm{O}_{2}$ and fullerol affected the gene expression of the TIMPI enzyme (Figure 3C).

The protective effects of fullerol on IL-1 $\beta$-induced degeneration were also assessed in human NP cells. Human NP cells were treated with $10 \mathrm{ng} / \mathrm{mL}$ of IL- $1 \beta$ for up to 
A UV-vis
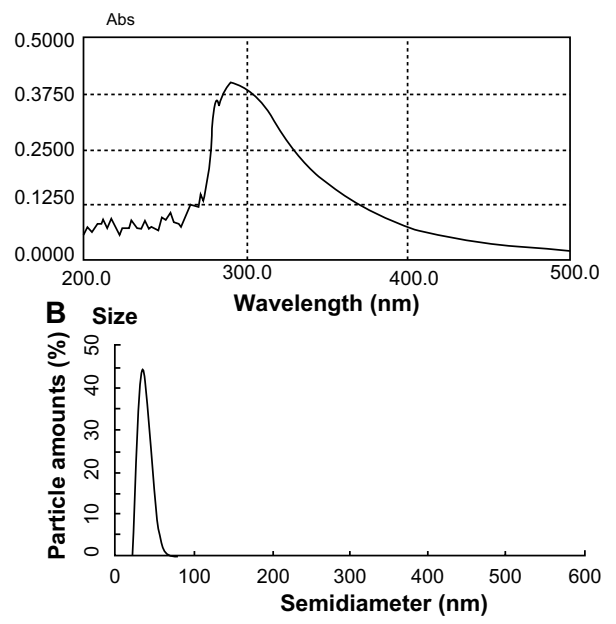

D Superoxide anion
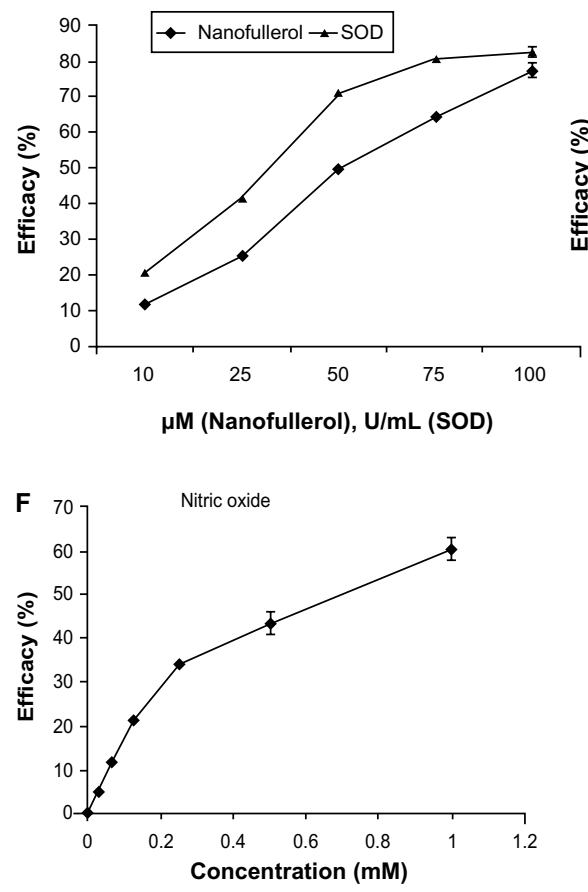

C Surface charge

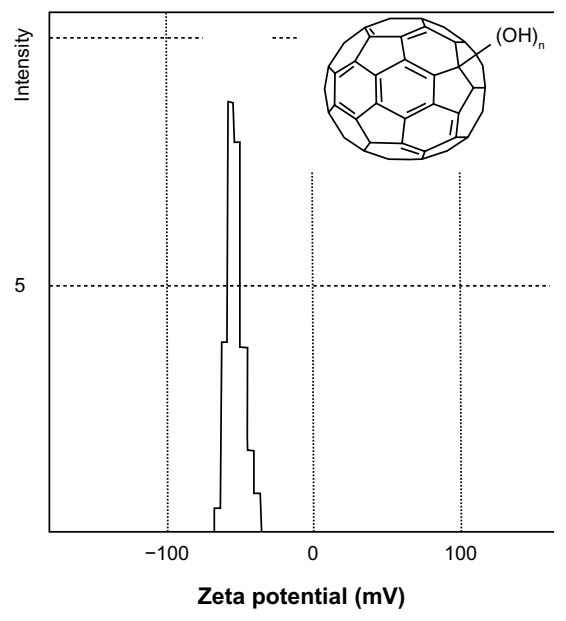

E Hydroxyl radical

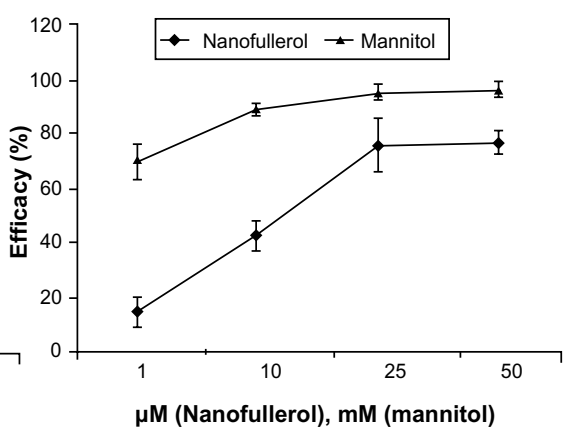

Figure I (A-F) Characterization of nanofullerol. Analysis of the ultraviolet-visible (UV-vis) spectrum (A), size distribution (B), and surface charge (C) indicated that the aqueous nanoparticles of fullerol had a characteristic absorption peak at $293 \mathrm{~nm}$, a narrow size range of $25-45 \mathrm{~nm}$, and a negative surface charge from $-40 \mathrm{mV}$ to $-60 \mathrm{mV}$. The insert in (C) illustrates the chemical structure of fullerol. Nanofullerol was also proven to be able to scavenge various reactive oxygen species, including superoxide anions (D), hydroxyl radicals $(\mathbf{E})$, and nitric oxide $(\mathbf{F})$.

Abbreviations: SOD, superoxide dismutase; Abs, absorbance.

7 days in the presence or absence of fullerol. IL-1 $\beta$ caused an increase in NO secretion at day 3 (Figure 4A), as well as a decrease in cellular proteoglycan content at both day 3 and day 7 (Figure 4B and C). Fullerol elicited a significant counteraction against the IL-1 $\beta$ effects (Figure 4A-C). Gene expression analysis by real-time RT-PCR showed that IL-1 $\beta$ induced a robust decrease in mRNA levels of aggrecan and COL $I$ and $I I$ at day 7 (Figure 4D-F). Compared to IL-1 $\beta$ alone, cotreatment with fullerol rescued the mRNA expression of aggrecan and COL II but not COL I (Figure 4D-F). In addition, with nanofullerol itself, the expression of $C O L I I$ was significantly upregulated (Figure 4E).

\section{Nanofullerol counteracts in vivo disk degeneration in a rabbit annulus- puncture model}

The protective effect of nanofullerol on disk degeneration was tested in a rabbit disk-degeneration model. ${ }^{35}$ The GAG content 


\section{A LDH assay}

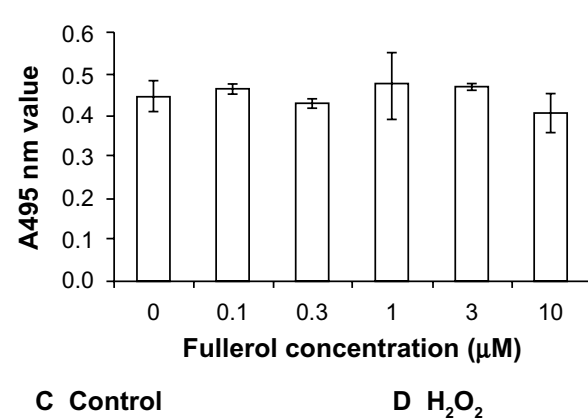

\section{B Live/dead assay}

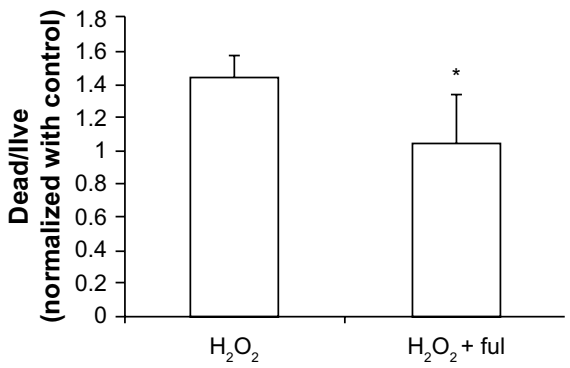

E $\mathrm{H}_{2} \mathrm{O}_{2}+$ fullerol
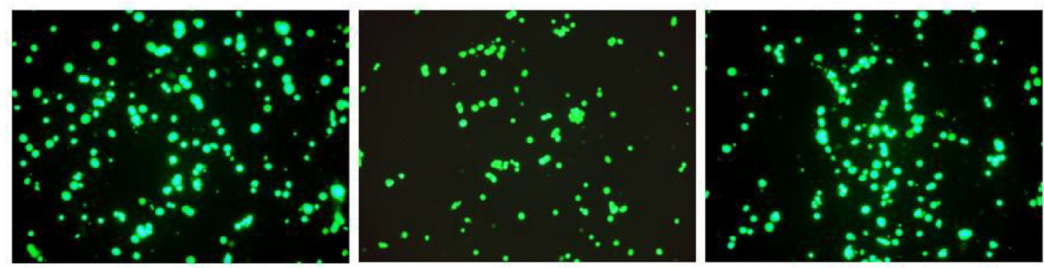

F Control

$\mathrm{G} \mathrm{H}_{2} \mathrm{O}_{2}$

H $\mathrm{H}_{2} \mathrm{O}_{2}+$ fullerol
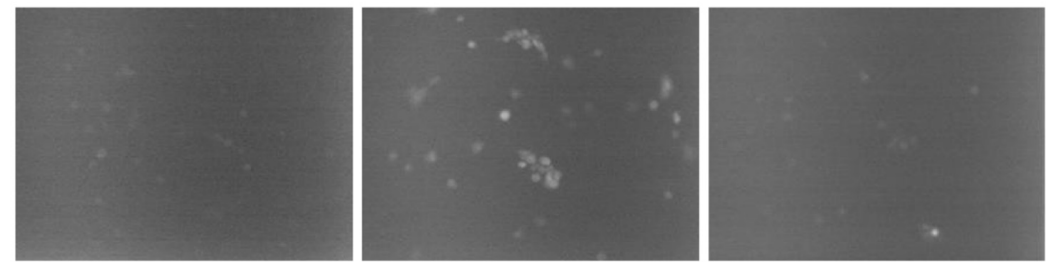

Figure $2(\mathbf{A}-\mathbf{H})$ Cytotoxicity and reactive oxygen species detection in human nucleus pulposus cells. (A) Cells were cultured in a monolayer and treated with different doses of fullerol for 4 hours, and the medium was collected for the lactate dehydrogenase (LDH) assay. (B-H) Cells were cultured in alginate beads and stained with different fluorescent dyes probing cell viability (B-E) and reactive oxygen species $(\mathbf{F}-\mathbf{H})$ after being treated with $\mathrm{H}_{2} \mathrm{O}_{2}(500 \mu \mathrm{M})$ alone or together with fullerol (Ful; I $\mu$ M) for 4 hours. Bar $50 \mu \mathrm{m}$. (B) Ratio of dead versus live cells quantified by Imagej software. Five randomly selected areas with more than 200 cells in total in each sample were calculated. Fullerol was able to inhibit $\mathrm{H}_{2} \mathrm{O}_{2}$-induced cell damage and overloaded oxidative stress. Note: $* P<0.05$

in the degenerated disks was greatly diminished by puncture injury, but was partly recovered by nanofullerol treatment at both the 4- and 12-week points (Figures 5A and 6A). MRI scans at 4 and 12 weeks showed a blurred AF-NP junction, narrowed disk space, and a lower $\mathrm{T}_{2}$-weighted MRI signal, indicating disk degeneration of the punctured disks. However, fullerol-injected disks showed a distinct AF-NP junction and strong $\mathrm{T}_{2}$-weighted MRI signals (Figures 5B and 6B). Safranin $\mathrm{O}$ staining demonstrated that ectopic bone formed in the annulus of the punctured disk, but not in those treated with nanofullerol (Figure 5C-E). The degree of ectopic bone formation was much greater at 12 weeks than at 4 weeks. Bone formation was completely inhibited in the presence of nanofullerol (Figure 6C-E) at 12 weeks.

\section{Discussion}

Current therapies for disk degeneration include nonsurgical treatment modalities (ie, physical therapy) or surgical intervention. ${ }^{36,37}$ However, neither nonsurgical nor surgical therapy restore functional native disk tissue, or regenerate the degenerated disk tissue, resulting in chronic inflammatory pain. Therefore, attempts are being made to seek effective biological alternatives so that the damaged tissue can be recovered both in structure and functionality. ${ }^{38-40}$ Many growth factors, such as insulin-like growth factor $1,{ }^{41}$ platelet-derived growth factor, ${ }^{41}$ osteogenic protein (OP)-1, ${ }^{42}$ bone morphogenetic protein $2,{ }^{43}$ and growth-differentiation factor $5,{ }^{44}$ have been shown to increase matrix production and cell proliferation while preventing apoptotic events. However, protein treatment is limited by the high cost of preparation and short half-lives. ${ }^{45}$ To address these concerns, efforts have been made to explore nonprotein candidates for disk-regeneration therapy. Several specific caspase inhibitors were found to prevent cell apoptosis in rat intervertebral disks. ${ }^{22,46}$ An inhibitor of p38 mitogen-activated protein kinase protected rabbit NP cells from damage caused by IL-1. ${ }^{21,47}$ However, the results are inconclusive, and apparently other effective biological treatment strategies are needed. 


\section{A GAG assay}

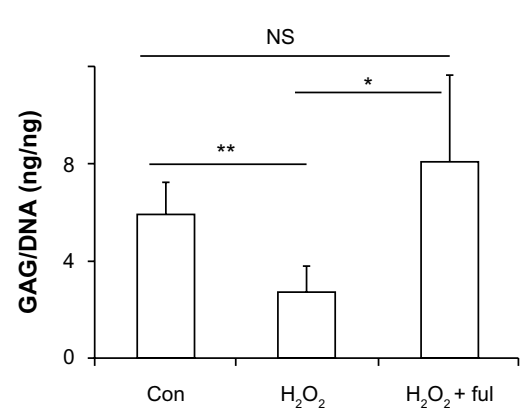

B: Immunofluorescence

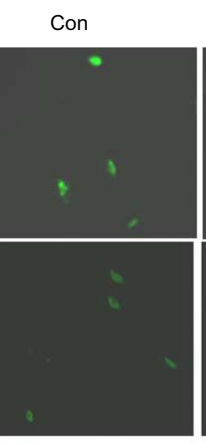

$\mathrm{H}_{2} \mathrm{O}_{2}$

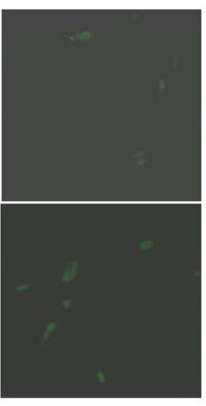

$\mathrm{H}_{2} \mathrm{O}_{2}+$ ful

C Real-time RT-PCR
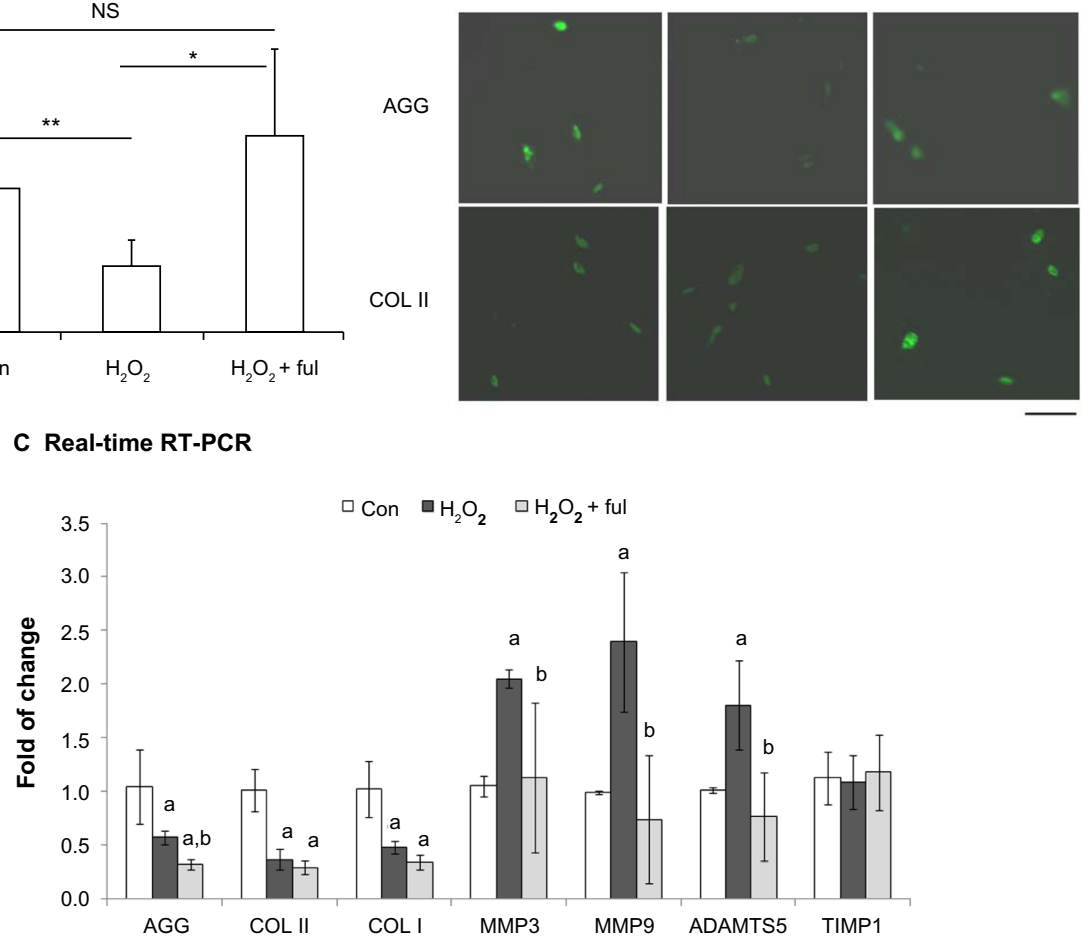

Figure 3 (A-C) Fullerol rescues impairment of extracellular matrix production induced by overloaded oxidative stress. Human nucleus pulposus cells in alginate beads were treated with $\mathrm{H}_{2} \mathrm{O}_{2}(500 \mu \mathrm{M})$ alone or together with fullerol (Ful; I $\mu \mathrm{M}$ ) for 4 hours and cultured for an additional 60 hours. (A) Cellular proteoglycan determined by a colorimetric method using the dimethylmethylene blue reagent. (B) Extracellular matrix production by immunofluorescence. Bar $50 \mu$ m. (C) The messenger ribonucleic acid expression of genes related to extracellular matrix was detected by real-time reverse transcription polymerase chain reaction (RT-PCR). Letters a and $b$ denote $P<0.05$ versus control (Con) and $P<0.05$ versus $\mathrm{H}_{2} \mathrm{O}_{2}$ groups, respectively.

Notes: $* P<0.05 ; * * P<0.01$.

Abbreviations: GAG, glycosaminoglycan; DNA, deoxyribonucleic acid; AGG, aggrecan; COL, collagen; MMP, matrix metalloproteinase; ADAMTS, a disintegrin and metalloproteinase with thrombospondin motifs; TIMP, tissue inhibitor of metalloproteinase; NS, not significant.

In recent years, numerous studies have demonstrated that oxidative stress plays an important role in the initiation and progression of disk degeneration. ${ }^{16-26}$ These reports led us to seek an antioxidative therapy for alleviating oxidative stress on cells that may allow a slow but controlled regeneration of disk. The purpose of the present study was to investigate the potential therapeutic effects of an antioxidant compound on disk degeneration in vitro and in vivo. Although fullerenes are good antioxidants, their formulation for administration and bioavailability is challenging, because of the material's highly hydrophobic properties. Among numerous reported fullerene derivatives, nanofullerol is the most extensively studied, and has been implicated as a powerful antioxidant in the biomedical field. ${ }^{48-56}$ Therefore, fullerol was selected in our present study.

We first characterized nanofullerol particles in water. ${ }^{34}$ The nanoparticle suspension had a characteristic UV-vis spectrum, ${ }^{34}$ and importantly the nanoparticles had a size distribution of $25-45 \mathrm{~nm}$, which was reported as an ideal size range for biological tissues uptake (Figure $1 \mathrm{~A}-\mathrm{C}$ ). ${ }^{57}$
Furthermore, our data showed that nanofullerol had extensive capability to remove ROS when compared to two typical ROS scavengers: the superoxide-anion scavenger SOD and the hydroxyl radical scavenger mannitol (Figure 1D-F).

It has been demonstrated that fullerol may have cytotoxicity to certain cell types, and it has also been reported that light irradiation along with fullerol treatment can cause cell cytotoxicity. ${ }^{58-61}$ Before evaluating the therapeutic utility of fullerol, we wanted to define the therapeutic window of dose availability for our studies using NP cells. Upon performing a dose-dependent LDH cytotoxicity assay as a measure of toxicity, we observed no apparent cytotoxicity up to $10 \mu \mathrm{M}$, tenfold higher than what we chose for our studies (Figure 2A). We did not observe any obvious changes in morphology or cell-culture behavior of NP cells at $1 \mu \mathrm{M}$ concentration. Furthermore, our results indicate that nanofullerol protected NP cells from ROS and cellular damage induced by $\mathrm{H}_{2} \mathrm{O}_{2}$ (Figure $2 \mathrm{~B}-\mathrm{H}$ ). These results are in accordance with those previously reported that nanofullerol provided protection against cell death induced by ROS 
A Nitrite test/3 days
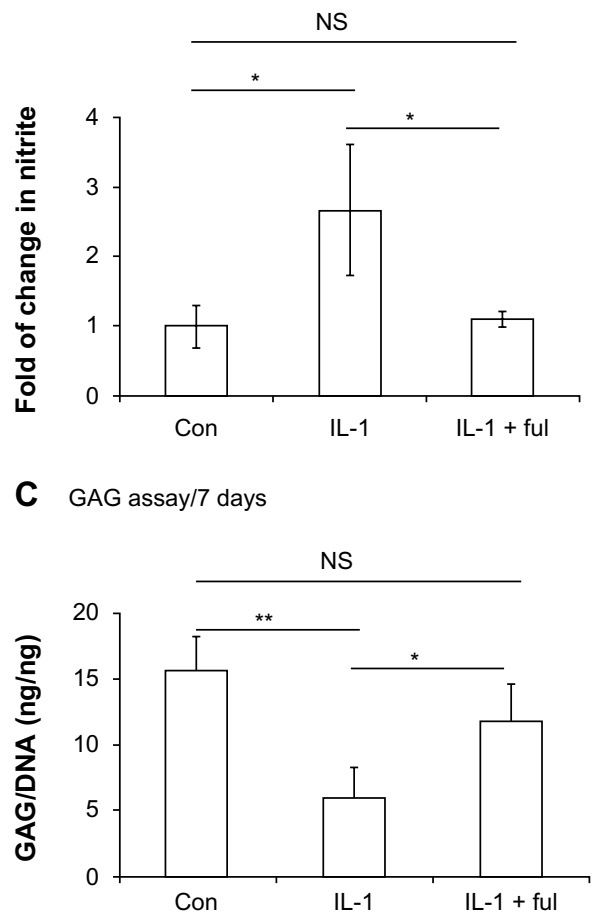

E $\operatorname{COL~II/7~days~}$

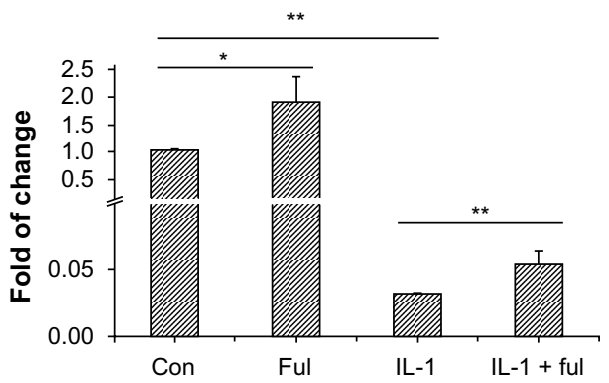

B GAG assay/3 days

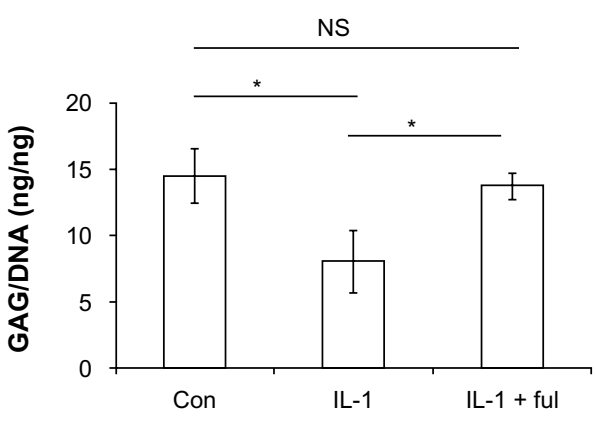

D $A G G / 7$ days

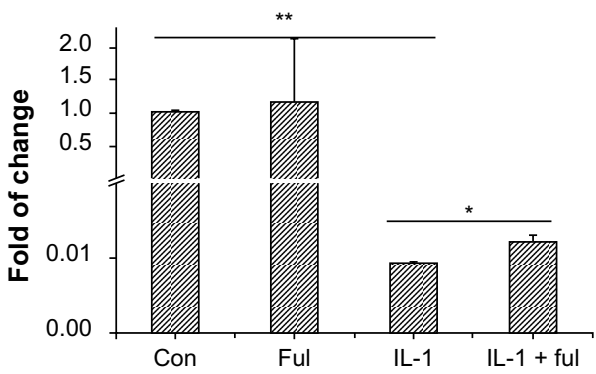

F $\quad$ COL I/7 days

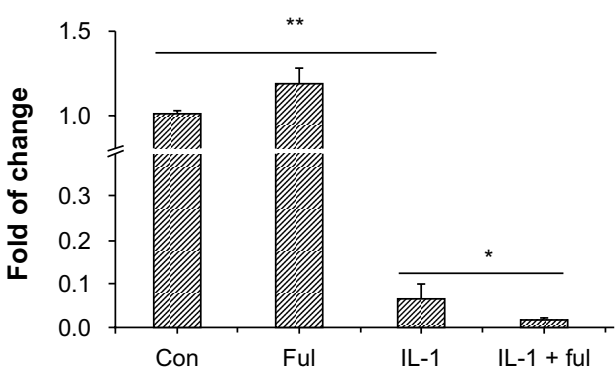

Figure 4 (A-F) Fullerol inhibits nitric oxide production and extracellular matrix destruction induced by interleukin (IL)-I. Human nucleus pulposus cells in alginate beads were treated with IL-I ( $10 \mathrm{ng} / \mathrm{mL})$ alone or together with fullerol (Ful; I $\mu \mathrm{M})$ for 3 days (A and B) or 7 days (C-F). (A) Nitrite level in culture medium was tested by Griess reagent. (B and $\mathbf{C}$ ) Cellular proteoglycan was determined by a colorimetric method using dimethylmethylene blue. (D-F) Gene expression of extracellular matrix proteins was assessed by real-time reverse transcription polymerase chain reaction.

Notes: $* P<0.05 ; * * P<0.01$.

Abbreviations: GAG, glycosaminoglycan; DNA, deoxyribonucleic acid; AGG, aggrecan; COL, collagen; NS, not significant; Con, control.

in a variety of cells and tissues, including keratinocytes ${ }^{62}$ and endothelial, ${ }^{63}$ heart, liver, kidney, testes, and lung tissues. $^{50,51,64,65}$

It is well known that GAGs are the dominant part of the proteoglycan aggrecan, and aggrecan is a major component of the extracellular matrix in both chondrocytes and NP cells. ${ }^{66,67}$ Yudoh et al reported that a water-soluble fullerene prevents matrix degradation in human chondrocytes under catabolic stress induced by $\mathrm{H}_{2} \mathrm{O}_{2}$ and IL- $1 \beta .{ }^{67}$ We investigated whether nanofullerol had a similar impact on NP cells, considering the similarity of these two cell types. It was demonstrated that these catabolic factors reduced extracellular matrix produc- tion through downregulation of the matrix proteins (aggrecan, COL I, and COL II) or upregulation of the matrix-degrading enzymes (MMP3, MMP9, and ADAMTS5) (Figures 3 and 4). As expected, nanofullerol displayed an antagonizing activity by scavenging ROS and increasing matrix proteins, as shown with the GAG assay and immunostaining, although real-time RT-PCR showed no change in COL or further decrease in aggrecan mRNA level (Figures 3 and 4). Further investigation should be made to interpret the inconsistent outcomes for mRNA and protein level of aggrecan. Taken together, these data indicate that nanofullerol rescues the degenerated phenotypes of human NP cells from oxidative or inflamma- 


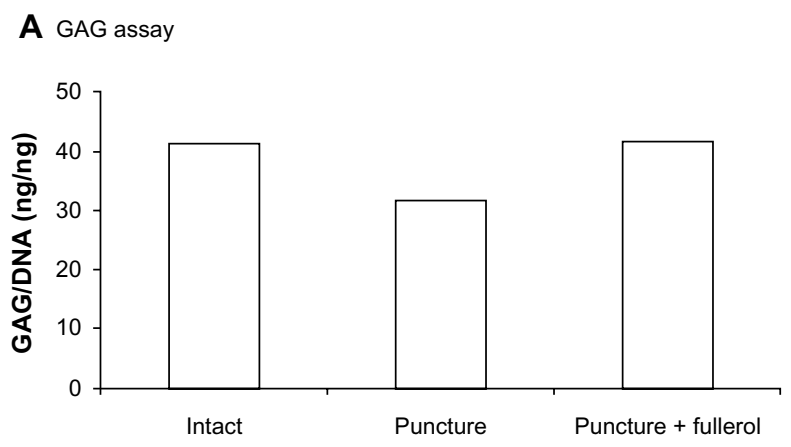

B MRI
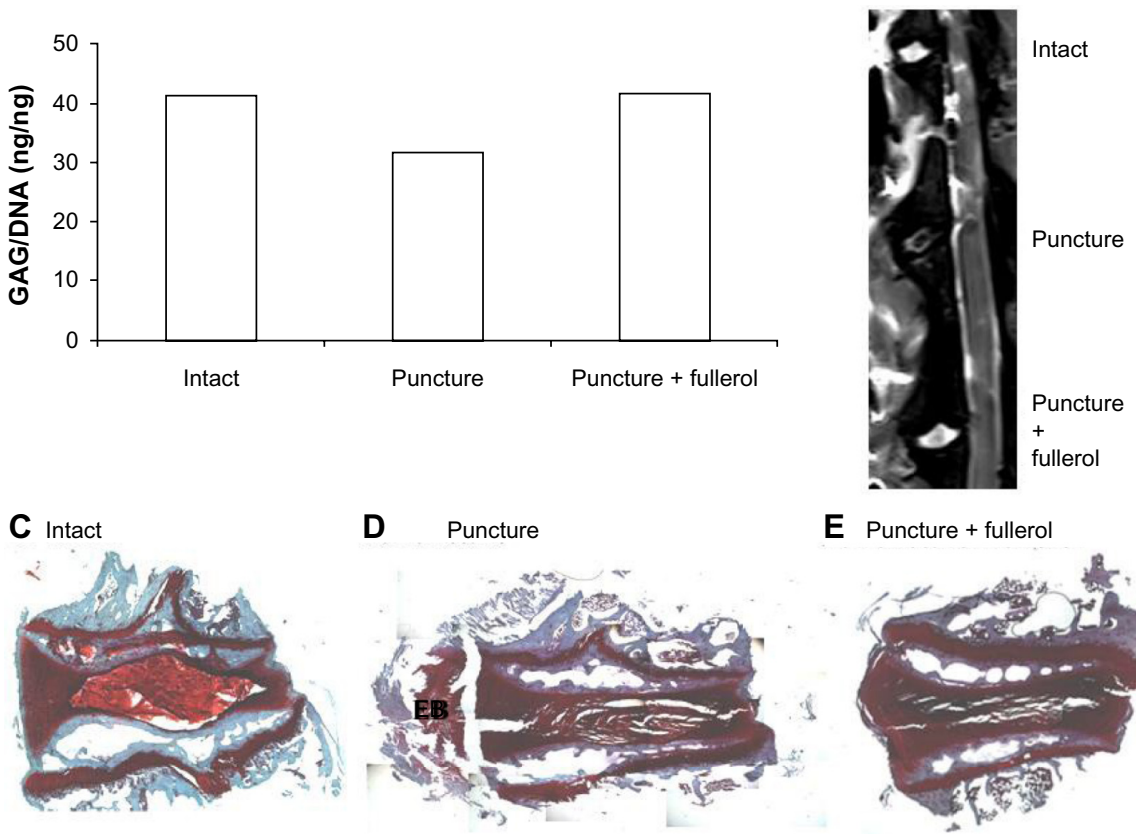

E Puncture + fullerol

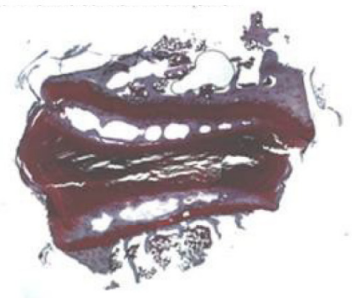

Figure 5 (A-E) Fullerol prevents disk degeneration in a rabbit annulus-puncture model at 4 weeks. (A) Quantification of proteoglycan in disk tissues; (B) magnetic resonance imaging (MRI) scanning of disk structure; (C-E) ectopic bone formation by Safranin O staining.

Notes: Annulus puncture was created with an $18 \mathrm{G}$ needle and simultaneously intradiskally injected with either phosphate-buffered saline or fullerol (I $\mu \mathrm{g} / \mathrm{disk})$. Four weeks later, lumbar spines were separated for MRI scan (B); disk tissues were collected for GAG assay (A); individual disks were decalcified, cut into $8 \mu \mathrm{m}$ slices, and stained with Safranin O (C-E).

Abbreviations: GAG, glycosaminoglycan; DNA, deoxyribonucleic acid; EB, ectopic bone.

tory stress. Previous studies have demonstrated that through the inhibition of oxidative stress, fullerol repressed the intracellular lipid accumulation in OP9 preadipocytes and D1 mesenchymal stem cells, and suppressed mitochondrial dysfunction in a model of Parkinson's disease. ${ }^{50,68-71}$ These data support the notion that nanofullerol is an effective ROS scavenger that can modulate multiple pathological processes related to $\mathrm{ROS}$.

The annulus-puncture model with progressive disk degeneration has been extensively used to evaluate various

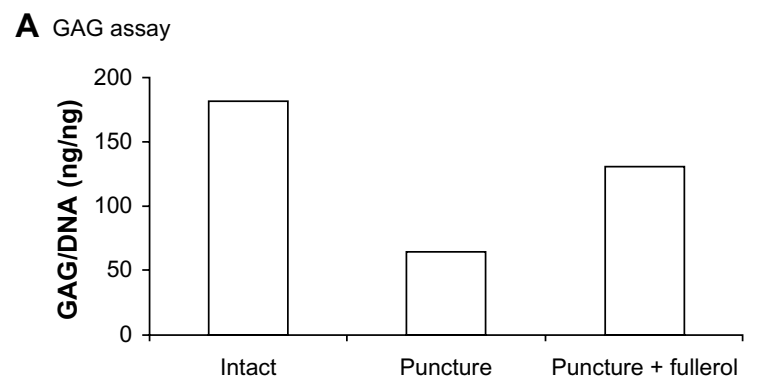

C Intact

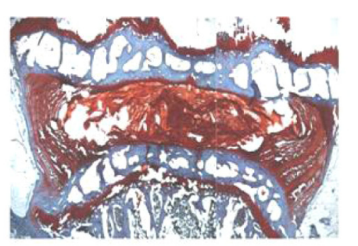

D Puncture

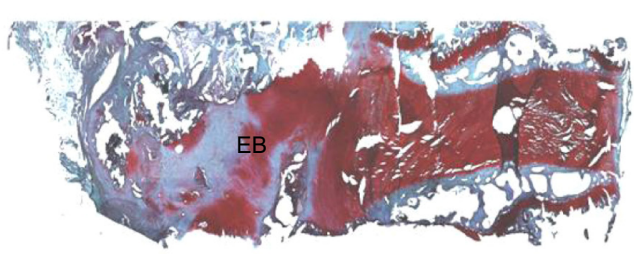

B MRI

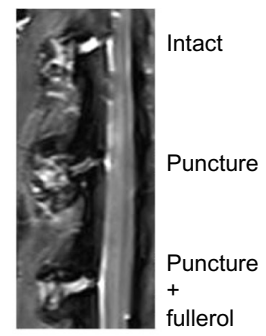

E Puncture + fullerol

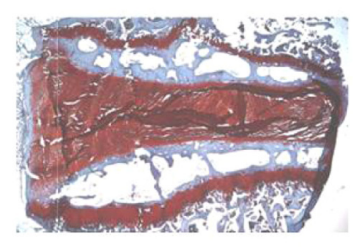

Figure 6 (A-E) Fullerol prevents disk degeneration in a rabbit annulus-puncture model at 12 weeks. (A) GAG content; (B) MRI analysis; (C-E) Safranin O staining.

Notes: Annulus puncture was created with an $18 \mathrm{G}$ needle and simultaneously intradiskally injected with either phosphate-buffered saline or fullerol (I $\mu$ g/disk). Twelve weeks later, lumbar spines were separated for MRI scan (B); disk tissues were collected for GAG assay (A); individual disks were decalcified, cut into $8 \mu \mathrm{m}$ slices, and stained with Safranin O (C-E).

Abbreviations: GAG, glycosaminoglycan; DNA, deoxyribonucleic acid; EB, ectopic bone; MRI, magnetic resonance imaging. 
remedies in rabbits. ${ }^{44,72,73}$ Increased levels of NO and IL-1 $\beta$ have been described in this disk-degeneration model. ${ }^{74}$ The encouraging outcomes from our in vitro experiments enabled us to conduct a pilot study to assess the efficacy of nanofullerol on preventing disk degeneration. Intradiskal injection of nanofullerol effectively protected the degenerated phenotypes of the injured disks by increasing the disk water-retaining capacity, inhibiting ectopic bone formation, and stimulating matrix production (Figures 5 and 6). One limitation of this study is that we used only one dose of nanofullerol (1 $\mu \mathrm{g}$ per disk). This concentration is comparable to that of growth factors used in degenerated disk treatment ${ }^{44}$ or a water-soluble fullerene used in degenerated knee joints. ${ }^{67}$ The pharmacokinetics and optimized doses are currently under investigation.

Nerlich et al reported that carboxymethyllysine (CML) is associated with ROS accumulation in the NP tissue, and that CML was closely related to disk degeneration. ${ }^{75}$ They indicated that CML activated a receptor of advanced glycation end products (RAGE)-nuclear factor (NF)- $\mathrm{KB}$ system in aging and degenerative intervertebral disks. The activation of RAGE-NFKB promoted the gene expression of nitric oxide synthase and MMPs. ${ }^{16}$ It is not clear whether nanofullerol defends disk degeneration by modifying CML and its signaling pathway, and this is currently under investigation.

There are several limitations in the current study. First, an oxygen level less than 5\% (ie, hypoxic atmosphere), rather than an oxygen level of $21 \%$ (ie, normoxic atmosphere), is considered to be closer to the in vivo environment where NP cells reside. It was reported that NP cells in hypoxic culture expressed favorable matrix composition compared to the normoxic culture. ${ }^{66}$ Therefore, it was worthwhile to apply a hypoxic model for assessing the effects of fullerol. Secondly, an acute annulus-puncture model was used to create disk degeneration in rabbits. Although this model has been widely used, its limitation is obvious, since multiple factors rather than a single injury factor are involved in the induction of disk degeneration in humans. Therefore, other models, especially a slow-progression model, such as a spontaneous sand rat model, are desirable for further investigation. ${ }^{76}$ Lastly, in the present experiments, fullerol was administered simultaneously with the induction of degeneration, and only the preventive activity of fullerol was studied. In this sense, the current findings are very preliminary, and additional experiments should be undertaken in which degeneration is established prior to the administration of fullerol.

\section{Conclusion}

This study presented in vitro and in vivo evidence supporting the view that the potent antioxidant fullerol rescues disk degeneration, pointing to a novel potential therapeutic remedy for the treatment of disk degeneration.

\section{Acknowledgments}

We appreciate the financial support from NIH 1R21AR05751201A2 and the North American Spine Society (NASS). We greatly appreciate the editing help from Mr Michael Ellwood and Mr Phillip Scott at the University of Virginia.

\section{Disclosure}

The authors report no conflicts of interest in this work.

\section{References}

1. Guiot BH, Fessler RG. Molecular biology of degenerative disc disease. Neurosurgery. 2000;47(5):1034-1040.

2. Phillips FM, An H, Kang JD, Boden SD, Weinstein J. Biologic treatment for intervertebral disc degeneration: summary statement. Spine (Phila Pa 1976). 2003;28(Suppl 15):S99.

3. Haefeli M, Kalberer F, Saegesser D, Nerlich AG, Boos N, Paesold G. The course of macroscopic degeneration in the human lumbar intervertebral disc. Spine (Phila Pa 1976). 2006;31(14):1522-1531.

4. Kim KW, Kim YS, Ha KY, et al. An autocrine or paracrine Fas-mediated counterattack: a potential mechanism for apoptosis of notochordal cells in intact rat nucleus pulposus. Spine (Phila Pa 1976). 2005;30(11): 1247-1251.

5. Adams MA, Freeman BJ, Morrison HP, Nelson IW, Dolan P. Mechanical initiation of intervertebral disc degeneration. Spine (Phila Pa 1976). 2000;25(13):1625-1636.

6. Ariga K, Yonenobu K, Nakase T, et al. Mechanical stress-induced apoptosis of endplate chondrocytes in organ-cultured mouse intervertebral discs: an ex vivo study. Spine (Phila Pa 1976). 2003;28(14): 1528-1533.

7. Bibby SR, Urban JP. Effect of nutrient deprivation on the viability of intervertebral disc cells. Eur Spine J. 2004;13(8):695-701.

8. Kaigle A, Ekström L, Holm S, Rostedt M, Hansson T. In vivo dynamic stiffness of the porcine lumbar spine exposed to cyclic loading: influence of load and degeneration. J Spinal Disord. 1998;11(1):65-70.

9. Sivan SS, Tsitron E, Wachtel E, et al. Aggrecan turnover in human intervertebral disc as determined by the racemization of aspartic acid. J Biol Chem. 2006;281(19):13009-13014.

10. Wang DL, Jiang SD, Dai LY. Biologic response of the intervertebral disc to static and dynamic compression in vitro. Spine (Phila Pa 1976). 2007;32(23):2521-2528.

11. Horner HA, Urban JP. 2001 Volvo Award Winner in Basic Science Studies: Effect of nutrient supply on the viability of cells from the nucleus pulposus of the intervertebral disc. Spine (Phila Pa 1976). 2001;26(23):2543-2549.

12. Apel K, Hirt H. Reactive oxygen species: metabolism, oxidative stress, and signal transduction. Ann Rev Plant Biol. 2004;55:373-399.

13. Rodriguez R, Redman R. Balancing the generation and elimination of reactive oxygen species. Proc Natl Acad Sci U S A. 2005;102(9): 3175-3176.

14. Kousteni S. FoxOs: unifying links between oxidative stress and skeletal homeostasis. Curr Osteoporos Rep. 2011;9(2):60-66.

15. Ziskoven C, Jager M, Kircher J, et al. Physiology and pathophysiology of nitrosative and oxidative stress in osteoarthritic joint destruction. Can J Physiol Pharmacol. 2011;89(7):455-466. 
16. Nerlich AG, Bachmeier BE, Schleicher E, Rohrbach H, Paesold G, Boos N. Immunomorphological analysis of RAGE receptor expression and NF-kappaB activation in tissue samples from normal and degenerated intervertebral discs of various ages. Ann N Y Acad Sci. 2007;1096:239-248.

17. Furusawa N, Baba H, Miyoshi N, et al. Herniation of cervical intervertebral disc: immunohistochemical examination and measurement of nitric oxide production. Spine (Phila Pa 1976). 2001;26(10):1110-1116.

18. Kohyama K, Saura R, Doita M, Mizuno K. Intervertebral disc cell apoptosis by nitric oxide: biological understanding of intervertebral disc degeneration. Kobe J Med Sci. 2000;46(6):283-295.

19. Liu GZ, Ishihara H, Osada R, Kimura T, Tsuji H. Nitric oxide mediates the change of proteoglycan synthesis in the human lumbar intervertebral disc in response to hydrostatic pressure. Spine (Phila Pa 1976). 2001;26(2):134-141.

20. Rannou F, Richette P, Benallaoua M, et al. Cyclic tensile stretch modulates proteoglycan production by intervertebral disc annulus fibrosus cells through production of nitrite oxide. $J$ Cell Biochem. 2003;90(1):148-157.

21. Studer RK, Gilbertson LG, Georgescu H, Sowa G, Vo N, Kang JD. p38 MAPK inhibition modulates rabbit nucleus pulposus cell response to IL-1. J Orthop Res. 2008;26(7):991-998.

22. Kim KW, Ha KY, Lee JS, Rhyu KW, An HS, Woo YK. The apoptotic effects of oxidative stress and antiapoptotic effects of caspase inhibitors on rat notochordal cells. Spine (Phila Pa 1976). 2007;32(22): 2443-2448.

23. Gruber HE, Hoelscher GL, Ingram JA, Bethea S, Hanley EN. IGF-1 rescues human intervertebral annulus cells from in vitro stress-induced premature senescence. Growth Factors. 2008;26(4):220-225.

24. Hormel SE, Eyre DR. Collagen in the ageing human intervertebral disc: an increase in covalently bound fluorophores and chromophores. Biochim Biophys Acta. 1991;1078(2):243-250.

25. Ishii T, Tsuji H, Sano A, Katoh Y, Matsui H, Terahata N. Histochemical and ultrastructural observations on brown degeneration of human intervertebral disc. J Orthop Res. 1991;9(1):78-90.

26. Pearce RH, Grimmer BJ, Adams ME. Degeneration and the chemical composition of the human lumbar intervertebral disc. J Orthop Res. 1987;5(2):198-205.

27. Anilkumar P, Lu F, Cao L, et al. Fullerenes for applications in biology and medicine. Curr Med Chem. 2011;18(14):2045-2059.

28. Li J, Zhu B, Shao Y, Liu X, Yang X, Yu Q. Construction of anticoagulant poly(lactic acid) films via surface covalent graft of heparin-carrying microcapsules. Colloids Surf B Biointerfaces. 2009;70(1):15-19.

29. Sachindra NM, Bhaskar N. In vitro antioxidant activity of liquor from fermented shrimp biowaste. Bioresour Technol. 2008;99(18): 9013-9016.

30. Caillet S, Yu HL, Lessard S, Lamoureux G, Ajdukovic D, Lacroix M. Fenton reaction applied for screening natural antioxidants. Food Chem 2007;100(2):542-552.

31. Chaea HJ, Kim HR, Kang YJ, et al. Heme oxygenase-1 induction by (S)-enantiomer of YS-51 (YS-51S), a synthetic isoquinoline alkaloid, inhibits nitric oxide production and nuclear factor- $\mathrm{\kappa B}$ translocation in ROS $17 / 2.8$ cells activated with inflammatory stimulants. Int Immunopharmacol. 2007;7(12):1559-1568.

32. Yang X, Wan Y, Qiao X, Arlet V, Li X. Transcriptional alteration of matrix-related gene expression in cultured human disc cells by nanoparticles of a bismethanophosphonate fullerene. Cell Biol Int. 2010;34(8):837-844.

33. Yang XL, Wang DD, Hao JR, et al. Enhancement of matrix production and cell proliferation in human annulus cells under bioreactor culture. Tissue Eng Part A. 2011;17(11-12):1595-1603.

34. Brant JA, Labille J, Robichaud CO, Wiesner M. Fullerol cluster formation in aqueous solutions: implications for environmental release. J Colloid Interface Sci. 2007;314(1):281-288.

35. Sobajima S, Shimer AL, Chadderdon RC, et al. Quantitative analysis of gene expression in a rabbit model of intervertebral disc degeneration by real-time polymerase chain reaction. Spine J. 2005;5(1):14-23.
36. Freemont TJ, LeMaitre C, Watkins A, Hoyland JA. Degeneration of intervertebral discs: current understanding of cellular and molecular events, and implications for novel therapies. Expert Rev Mol Med. 2001;2001:1-10.

37. Slade SC, Keating JL. Unloaded movement facilitation exercise compared to no exercise or alternative therapy on outcomes for people with nonspecific chronic low back pain: a systematic review. J Manipulative Physiol Ther. 2007;30(4):301-311.

38. Masuda K, An HS. Prevention of disc degeneration with growth factors. Eur Spine J. 2006;15 Suppl 3:S422-S432.

39. Paesold G, Nerlich AG, Boos N. Biological treatment strategies for disc degeneration: potentials and shortcomings. Eur Spine $J$. 2007;16(4):447-468.

40. Zhang Y, An HS, Tannoury C, Thonar EJ, Freedman MK, Anderson DG. Biological treatment for degenerative disc disease: implications for the field of physical medicine and rehabilitation. Am J Phys Medicine Rehabil. 2008;87(9):694-702.

41. Gruber HE, Norton HJ, Hanley EN Jr. Anti-apoptotic effects of IGF-1 and PDGF on human intervertebral disc cells in vitro. Spine (Phila Pa 1976). 2000;25(17):2153-2157.

42. Masuda K, Imai Y, Okuma M, et al. Osteogenic protein-1 injection into a degenerated disc induces the restoration of disc height and structural changes in the rabbit anular puncture model. Spine (Phila Pa 1976). 2006;31(7):742-754.

43. Huang KY, Yan JJ, Hsieh CC, Chang MS, Lin RM. The in vivo biological effects of intradiscal recombinant human bone morphogenetic protein-2 on the injured intervertebral disc: an animal experiment. Spine (Phila Pa 1976). 2007;32(11):1174-1180.

44. Chujo T, An HS, Akeda K, et al. Effects of growth differentiation factor-5 on the intervertebral disc - in vitro bovine study and in vivo rabbit disc degeneration model study. Spine (Phila Pa 1976). 2006;31(25): 2909-2917.

45. Goupille P, Mulleman D, Chevalier X. Is interleukin-1 a good target for therapeutic intervention in intervertebral disc degeneration: lessons from the osteoarthritic experience. Arthritis Res Ther. 2007; 9(6): 110.

46. Park JB, Park IC, Park SJ, Jin HO, Lee JK, Riew KD. Anti-apoptotic effects of caspase inhibitors on rat intervertebral disc cells. J Bone Joint Surg Am. 2006;88(4):771-779.

47. Studer RK, Aboka AM, Gilbertson LG, et al. p38 MAPK inhibition in nucleus pulposus cells: a potential target for treating intervertebral disc degeneration. Spine (Phila Pa 1976). 2007;32(25):2827-2833.

48. Bogdanović G, Kojić V, Dordević A, Canadanović-Brunet J, Vojinović-Miloradov M, Baltić VV. Modulating activity of fullerol $\mathrm{C} 60(\mathrm{OH}) 22$ on doxorubicin-induced cytotoxicity. Toxicol In Vitro. 2004;18(5):629-637.

49. Vapa I, Torres VM, Djordjevic A, et al. Effect of fullerenol C(60)(OH) (24) on lipid peroxidation of kidneys, testes and lungs in rats treated with doxorubicine. Eur J Drug Metab Pharmacokinet. 2012;37(4): 301-307.

50. Torres VM, Srdjenovic B, Jacevic V, Simic VD, Djordjevic A, Simplício AL. Fullerenol $\mathrm{C} 60(\mathrm{OH}) 24$ prevents doxorubicin-induced acute cardiotoxicity in rats. Pharmacol Rep. 2010;62(4):707-718.

51. Srdjenovic B, Milic-Torres V, Grujic N, Stankov K, Djordjevic A, Vasovic V. Antioxidant properties of fullerenol $\mathrm{C} 60(\mathrm{OH}) 24$ in rat kidneys, testes, and lungs treated with doxorubicin. Toxicol Mech Methods. 2010;20(6):298-305.

52. Injac R, Perse M, Obermajer N, et al. Potential hepatoprotective effects of fullerenol $\mathrm{C} 60(\mathrm{OH}) 24$ in doxorubicin-induced hepatotoxicity in rats with mammary carcinomas. Biomaterials. 2008;29(24-25):3451-3460.

53. Injac R, Perse M, Boskovic M, et al. Cardioprotective effects of fullerenol $\mathrm{C}(60)(\mathrm{Oh})(24)$ on a single dose doxorubicin-induced cardiotoxicity in rats with malignant neoplasm. Technol Cancer Res Treat. 2008;7(1):15-25.

54. Mirkov SM, Djordjevic AN, Andric NL, et al. Nitric oxide-scavenging activity of polyhydroxylated fullerenol, $\mathrm{C} 60(\mathrm{OH}) 24$. Nitric Oxide. 2004;11(2):201-207. 
55. Lai HS, Chen Y, Chen WJ, Chang J, Chiang LY. Free radical scavenging activity of fullerenol on grafts after small bowel transplantation in dogs. Transplant Proc. 2000;32(6):1272-1274.

56. Tsai MC, Chen YH, Chiang LY. Polyhydroxylated C60, fullerenol, a novel free-radical trapper, prevented hydrogen peroxide- and cumene hydroperoxide-elicited changes in rat hippocampus in-vitro. J Pharm Pharmacol. 1997;49(4):438-445.

57. Yang JH, Wang K, Driver J, Yang JH, Barron AR. The use of fullerene substituted phenylalanine amino acid as a passport for peptides through cell membranes. Org Biomol Chem. 2007;5(2):260-266.

58. Su Y, Xu JY, Shen P, et al. Cellular uptake and cytotoxic evaluation of fullerenol in different cell lines. Toxicology. 2010;269(2-3): 155-159.

59. Saathoff JG, Inman AO, Xia XR, Riviere JE, Monteiro-Riviere NA. In vitro toxicity assessment of three hydroxylated fullerenes in human skin cells. Toxicol In Vitro. 2011;25(8):2105-2112.

60. Roberts JE, Wielgus AR, Boyes WK, Andley U, Chignell CF. Phototoxicity and cytotoxicity of fullerol in human lens epithelial cells. Toxicol Appl Pharmacol. 2008;228(1):49-58.

61. Zha YY, Yang B, Tang ML, et al. Concentration-dependent effects of fullerenol on cultured hippocampal neuron viability. Int J Nanomedicine. 2012;7:3099-3109.

62. Xiao L, Takada H, Maeda K, Haramoto M, Miwa N. Antioxidant effects of water-soluble fullerene derivatives against ultraviolet ray or peroxylipid through their action of scavenging the reactive oxygen species in human skin keratinocytes. Biomed Pharmacother. 2005;59(7):351-358.

63. Lao F, Li W, Han D, et al. Fullerene derivatives protect endothelial cells against NO-induced damage. Nanotechnology. 2009;20(22):225103.

64. Chen YW, Hwang KC, Yen CC, Lai YL. Fullerene derivatives protect against oxidative stress in RAW 264.7 cells and ischemia-reperfused lungs. Am J Physiol Regul Integr Comp Physiol. 2004;287(1): R21-R26.

65. Injac R, Perse M, Cerne M, et al. Protective effects of fullerenol $\mathrm{C}-60(\mathrm{OH})(24)$ against doxorubicin-induced cardiotoxicity and hepatotoxicity in rats with colorectal cancer. Biomaterials. 2009;30(6): 1184-1196.

66. Mwale F, Ciobanu I, Giannitsios D, Roughley P, Steffen T, Antoniou J. Effect of oxygen levels on proteoglycan synthesis by intervertebral disc cells. Spine (Phila Pa 1976). 2011;36(2):E131-E138.
67. Yudoh K, Shishido K, Murayama H, et al. Water-soluble c60 fullerene prevents degeneration of articular cartilage in osteoarthritis via down-regulation of chondrocyte catabolic activity and inhibition of cartilage degeneration during disease development. Arthritis Rheum. 2007;56(10):3307-3318.

68. Saitoh Y, Mizuno H, Xiao L, Hyoudou S, Kokubo K, Miwa N. Polyhydroxylated fullerene $\mathrm{C}_{60}(\mathrm{OH})_{44}$ suppresses intracellular lipid accumulation together with repression of intracellular superoxide anion radicals and subsequent PPAR $\gamma 2$ expression during spontaneous differentiation of OP9 preadipocytes into adipocytes. Mol Cell Biochem. 2012;366(1-2):191-200.

69. Saitoh Y, Xiao L, Mizuno H, et al. Novel polyhydroxylated fullerene suppresses intracellular oxidative stress together with repression of intracellular lipid accumulation during the differentiation of OP9 preadipocytes into adipocytes. Free Radic Res. 2010;44(9):1072-1081.

70. Cai X, Jia H, Liu Z, et al. Polyhydroxylated fullerene derivative C(60) $(\mathrm{OH})(24)$ prevents mitochondrial dysfunction and oxidative damage in an MPP(+)-induced cellular model of Parkinson's disease. J Neurosci Res. 2008;86(16):3622-3634.

71. Liu H, Yang X, Zhang Y, Dighe A, Li X, Cui Q. Fullerol antagonizes dexamethasone-induced oxidative stress and adipogenesis while enhancing osteogenesis in a cloned bone marrow mesenchymal stem cell. J Orthop Res. 2012;30(7):1051-1057.

72. Sawamura K, Ikeda T, Nagae M, et al. Characterization of in vivo effects of platelet-rich plasma and biodegradable gelatin hydrogel microspheres on degenerated intervertebral discs. Tissue Eng Part A. 2009;15(12):3719-3727.

73. Sobajima S, Vadala G, Shimer A, Kim JS, Gilbertson LG, Kang JD. Feasibility of a stem cell therapy for intervertebral disc degeneration. Spine J. 2008;8(6):888-896.

74. Sobajima S, Kompel JF, Kim JS, et al. A slowly progressive and reproducible animal model of intervertebral disc degeneration characterized by MRI, X-ray, and histology. Spine (Phila Pa 1976). 2005;30(1):15-24.

75. Nerlich AG, Schleicher ED, Boos N. 1997 Volvo Award winner in basic science studies. Immunohistologic markers for age-related changes of human lumbar intervertebral discs. Spine (Phila Pa 1976). 1997;22(24):2781-2795.

76. Sun F, Qu JN, Zhang YG. Animal models of disc degeneration and major genetic strategies. Pain Physician. 2013;16(3):E267-E275.
International Journal of Nanomedicine

\section{Publish your work in this journal}

The International Journal of Nanomedicine is an international, peerreviewed journal focusing on the application of nanotechnology in diagnostics, therapeutics, and drug delivery systems throughout the biomedical field. This journal is indexed on PubMed Central, MedLine, CAS, SciSearch $\AA$, Current Contents ${ }^{\circledR} /$ Clinical Medicine,

\section{Dovepress}

Journal Citation Reports/Science Edition, EMBase, Scopus and the Elsevier Bibliographic databases. The manuscript management system is completely online and includes a very quick and fair peer-review system, which is all easy to use. Visit http://www.dovepress.com/ testimonials.php to read real quotes from published authors. 